\title{
IMPLEMENTASI NILAI EDUKATIF CERITA RAKYAT DARI KALIMANTAN BARAT 2 KARYA SYAHZAMAN DALAM RELEVANSI TERHADAP MATERI PEMBELAJARAN APRESIASI SASTRA
}

\author{
${ }^{1}$ Lizawati, ${ }^{2}$ Indriyana Uli \\ ${ }^{1}$ IKIP PGRI Pontianak \\ ${ }^{2}$ IKIP PGRI Pontianak \\ 1iyanauli@gmail.com
}

\begin{abstract}
Abstrak
Tujuan dari penelitian ini adalah untuk mendeskripsikan nilai edukatif serta relevansinya Cerita Rakyat dari Kalimantan Barat 2 karya Syahzaman terhadap materi pembelajaran apresiasi sastra di tingkat SMA. Teknik pengumpulan data menggunakan teknik analisis dokumen. dengan alat pengumpul data adalah peneliti sendiri sebagai instrument kunci. Teknik analisis data yang digunakan dalam penelitian ini adalah teknik analisis jalinan atau mengalir yang meliputi tiga komponen, yaitu reduksi data, sajian data, dan penarikan simpulan. Hasil analisis dapat ditarik kesimpulan yaitu pertama, ni edukatif terkandung dalam Cerita Rakyat dari Kalimantan Barat 2 karya Syahzaman berupa niali moral, nilai adat (tradisional), nilai budi pekerti, dan nilai sejarah yang memberikan gambaran kebiasaan baik prilaku masyarakat Kalimantan barat. Dan kedua, relevansi Cerita Rakyat dari Kalimantan Barat 2 karya Syahzaman terhadap pembelajaran di SMA relevan dengan kurikulum dan kebutuhan siswa pada saat ini. Relevansi tersebut juga tergambar dalam kurikukum 2013 yang diterapkan di sekolah-sekolah menengah atas dan sejalan dengan hasil wawancara bersama infoman.
\end{abstract}

Kata Kunci: Edukatif, Cerita Rakyat, Relevansi

\begin{abstract}
The purpose of this study was to describe the educational value and the relevance of Syahzaman's West Kalimantan 2 Folklore to literature appreciation learning material at the high school level. Data collection techniques use document analysis techniques. with a data collection tool is the researcher himself as a key instrument. The data analysis technique used in this study is a braid or flow analysis technique that includes three components, namely data reduction, data presentation, and drawing conclusions. The results of the analysis can be concluded that is first, this education is contained in Folklore from West Kalimantan 2 works of Syahzaman in the form of moral values, traditional (traditional) values, ethical values, and historical values that provide a description of the good habits of West Kalimantan people. And secondly, the relevance of Syahzaman's Folklore from West Kalimantan 2 to learning in high school is relevant to the curriculum and the needs of students at this time. This relevance is also reflected in the curriculum 2013 applied in high schools and in line with the results of interviews with the infoman.
\end{abstract}

Keywords: Educative, Folklore, Relevance 


\section{PENDAHULUAN}

Cerita rakyat merupakan salah satu sumber kekayaan tradisi yang perlu digali, dilestarikan, dan dikembangkan sebagai sumber kekuatan budaya. Selain itu, cerita rakyat yang baik dapat dijadikan materi alternatif dalam pembelajaran sastra di sekolah. Dalam cerita rakyat dapat diketahui sejarah, pengalaman, pandangan hidup, adat-istiadat, kepercayaan, politik, cita-cita, dan berbagai kegiatan lain yang terdapat di daerah tersebut. Hal ini berarti bahwa dalam cerita rakyat tersirat kenyataan yang menggambarkan keadaan masyarakat pada masa lalu. Kehidupan masyarakat pada masa lalu sangat menentukan kehidupan pada masa mendatang. Dengan demikian, apabila cerita-cerita rakyat yang hidup dan berkembang pada masa lalu digali dan dikembangkan sangat bermanfaat bagi kehidupan masa kini dan yang akan datang.

Cerita rakyat biasanya disebarkan secara lisan dari mulut ke mulut, bersifat tradisional, diwariskan dari satu generasi kepada generasi berikutnya, terdiri dari berbagai versi cerita, dan biasanya tidak diketahui pengarangnya (anonim), serta kadang-kadang penuturannya disertai dengan perbuatan, misalnya mengajarkan tari, membatik, mendalang, dan sebagainya. Hal-hal tersebut menjadi ciri penanda cerita-cerita rakyat yang tersebar di seluruh wilayah nusantara. Berkaitan dengan ciri-ciri sastra lisan, termasuk di dalamnya adalah cerita rakyat, Brunvand (1968: 4) menyatakan bahwa sastra lisan memiliki ciri-ciri antara lain (1) it is oral, (2) it is traditional, (3) it exist in different version, (4) it usually anonymous, (5) it tends to become formulized.

Cerita rakyat merupakan salah satu bentuk folklor yang banyak dijumpai di Indonesia, disampaikan secara lisan melalui bagian-bagian cerita kepahlawanan yang digambarkan seperti dalam wayang atau teater. Cerita rakyat tersebut telah dikumpulkan dan digunakan dalam sistem pendidikan di Indonesia melalui bukubuku kecil yang cukup murah. Cerita-cerita rakyat ini terdapat di daerah-daerah seluruh Indonesia.

Folklor dapat disejajarkan dengan tradisi lisan yang tidak terbatas pada mite dan legenda saja, tetapi dapat berupa sistem kognasi kekerabatan lengkap, perti sejarah, hukum adat, praktik hukum, dan pengobatan tradisional. Tol dan 
Prudentia (1995: 2) berpendapat bahwa oral traditions do not only contains folktales, myths and legends, but store complete indigenous cognate systems, to name a few hystoris, legal practices, adat law, medications. Danandjaja (1997: 14) menyatakan bahwa koleksi folklor Indonesia terdiri dari kepercayaan rakyat, upacara, cerita prosa rakyat (mite, legenda, dan dongeng), nyanyian anak-anak, olahraga bertanding, hasta karya, makanan dan minuman, arsitektur rakyat, teater rakyat, musik rakyat, logat, dan lain-lain.

Hutomo (1991: 3) menyatakan bahwa di dalam masyarakat tradisional, peranan sastra lisan lebih besar daripada sastra tulis. Sebaliknya, dalam masyarakat modern, peranan sastra tulis lebih besar daripada sastra lisan. Sastra lisan dalam masyarakat tradisional bersifat komunal, sedangkan sastra tulis dalam masyarakat modern bersifat individual yang bisa dinikmati perseorangan di dalam kamar atau di tempat-tempat lain.

Cerita rakyat yang jumlahnya ribuan dapat dijadikan sumber pembelajaran di sekolah-sekolah. Masyarakat luas juga perlu mempelajari khasanah budaya dari berbagai daerah sebagai upaya menggali, melestarikan, dan mengembangkan budaya-budaya daerah. Sumbangan yang sangat berharga dari budaya-budaya daerah akan sangat mendukung perkembangan budaya nasional. Cerita-cerita rakyat yang ditulis dalam bahasa daerah perlu dialihbahasakan ke dalam bahasa yang lebih luas jangkauannya. Cerita-cerita rakyat yang telah dialih bahasakan dari bahasa-bahasa daerah ke bahasa nasional dapat dijadikan sumber pembelajaran secara nasional, sehingga seluruh masyarakat Indonesia dapat mengapresiasinya. Dalam cerita rakyat dapat ditemukan gambaran kehidupan masyarakat pada masa lalu. Kehidupan masa lalu dapat dijadikan bahan refleksi untuk acuan di masa-masa mendatang. Oleh karena itu, cerita rakyat memiliki hubungan yang erat dengan realitas sosial yang terjadi dalam masyarakat. Melalui cerita rakyat dapat diketahui kekayaan budaya sendiri dan kebesaran masa lampau untuk dijadikan bahan dalam pembentukan nilai dan budaya sekarang dan masa-masa mendatang. Dengan demikian, cerita rakyat dapat dijadikan sebagai potret kehidupan masyarakat pada masa lampau dan sumber inspirasi di masa mendatang. 
Apresiasi masyarakat terhadap kehidupan cerita-cerita rakyat yang ada di daerah mengalami penurunan. Cerita-cerita rakyat tergeser oleh perkembangan ilmu pengetahuan dan teknologi yang mengusung cerita-cerita modern. Anakanak lebih asyik menonton televisi, film, dan mendengarkan lagu-lagu lewat casette, $\mathrm{VCD}$, dan hasil teknologi modern lainnya daripada mendengarkan dan mengapresiasi cerita-cerita rakyat yang ada di daerahnya. Mereka merasa asing terhadap kekayaan budaya lokal yang dimilikinya, padahal apabila dikaji secara mendalam, di dalam cerita-cerita rakyat yang ada di daerah tempat tinggalnya dapat ditemukan falsafah kehidupan, kearifan-kearifan lokal, nilai-nilai positif yang sesuai dengan latar belakang kehidupan mereka dan sangat berguna dalam kehidupannya.

Melihat fenomena seperti digambarkan di atas, perlu dilakukan upaya untuk menumbuhkan sosialisasi sastra beserta nilai-nilai yang terkandung di dalamnya terhadap generasi muda. Sosilaisasi sastra melalui bercerita atau mendongeng di lingkungan keluarga dapat dijadikan langkah praktis untuk menghidupkan kembali cerita-cerita rakyat di suatu daerah. Upaya serupa dapat dilakukan di lingkungan sekolah dengan mengangkat cerita-cerita rakyat sebagai materi pembelajaran bahasa dan sastra. Berkaitan dengan hal tersebut, cerita-cerita rakyat yang terdapat di daerah-daerah perlu diteliti dan dibukukan, karena cerita rakyat merupakan kekayaan budaya bangsa yang mengandung nilai-nilai luhur bagi kehidupan masyarakat.

Sejumlah nilai edukatif dapat ditemukan dalam cerita rakyat, melalui peristiwa, karakter, tokoh cerita, dan hubungan antartokoh. Nilai-nilai tersebut dapat digali dari percakapan antartokoh atau paparan latar cerita. Hal-hal yang positif maupun negatif dapat diketahui setelah karya sastra dibaca secara rekreatif dan kritis-analitis. Nilai-nilai edukatif tersebut dapat menambah kekayaan batin para penikmatnya. Jika digali secara mendalam, dalam cerita-cerita rakyat terdapat keteladanan-keteladanan dan petuah-petuah bijak melalui tokoh atau peristiwa, meskipun tidak disampaikan secara eksplisit. seseorang dapat menemukan nilai-nilai edukatif dalam sebuah cerita rakyat setelah cerita rakyat tersebut dipahami secara benar. 
Nilai-nilai dalam sebuah karya sastra dapat tergambar melalui tema-tema besar mengenai siapa manusia, keberadaannya di dunia dan dalam masyarakat (Sutrisna, 1997: 63). Apa itu kebudayaannya, proses pendidikannya, semua itu dipigurakan dalam refleksi konkrit fenomenal berdasarkan fenomena eksistensi manusia dan direfleksikan sebagai rentangan perjalanan bereksistensi.

Waluyo (1990: 27) mengemukakan bahwa nilai sastra adalah kebaikan yang ada dalam makna karya sastra bagi kehidupan. Nilai sastra dapat berupa nilai medial (menjadi sarana), nilai final (yang dikejar seseorang), nilai kultural, nilai kesusilaan, dan nilai agama. Setiap karya sastra yang baik, termasuk cerita rakyat, selalu mengungkapkan nilai-nilai luhur yang bermanfaat bagi pembacanya. Hal ini membuktikan bahwa karya sastra memiliki hubungan yang erat dengan nilainilai pendidikan.

Untuk memahami nilai-nilai dalam cerita rakyat secara benar, diperlukan kedalaman pikir dan keluasan wawasan, serta pemahaman yang menyeluruh terhadap budaya yang berlaku di setiap daerah agar dapat berimplementasi terhadap pembelajaran di sekolah. Hal penting perlu dilakukan guru dalam memilih cerita rakyat yang sesuai dengan kurikulum, pengembangan kebudayaan, dan psikologi peserta didik. Rusyana (2000: 4) memberikan rambu-rambu pemilihan cerita rakyat bagi peserta didik, antara lain (1) untuk kebudayaan lama dan asli dapat dipilih dari kebudayaan daerah, (2) untuk kebudayaan daerah adalah yang mengandung nilai-nilai luhur dengan kesadaran nasional, bukan yang bersifat feodal dan kedaerahan yang sempit, (3) untuk bahan-bahan dari kebudayaan asing adalah yang dapat memperkayakembangkan kebudayaan bangsa sendiri.

Suwandi (2008: 11-12) berpendapat bahwa terdapat implikasi penting terhadap masuknya cerita rakyat dalam kurikulum satuan pendidikan, anatar lain (1) guru perlu memiliki pemahaman yang lengkap tentang khasanah cerita rakyat yang dimiliki masyarakat Indonesia dari berbagai etnik dan mampu menjadikannya bahan ajar dalam hal struktur, isi, dan nilai-nilai edukatif, (2) guru dituntut mampu mengembangkan materi pembelajaran cerita rakyat dengan baik melalui seleksi materi yang sesuai dengan kurikulum dan nilai-nilai edukatif yang 
akan ditanamkan kepada peserta didik, (3) sekolah dan pemerintah perlu menyediakan cerita rakyat dari berbagai daerah dalam jumlah dan variasi cerita yang memadai, sehingga guru akan mampu dengan lebih baik menjadi fasilitator dan dinamisator kegiatan pembelajaran, meningkatkan kemampuan apresiasi peserta didik, dan menumbuhkembangkan wawasan multikultural mereka. Siswa perlu terus-menerus didorong untuk mau dan mampu menghargai keberbedaan, menegakkan nilai-nilai demokrasi, keadilan, dan kemanusiaan.

Sejalan dengan pendapat di atas, dalam Undang-undang Republik Indonesia Nomor 20 Tahun 2003 tentang Sistem Pendidikan Nasional dijelaskan bahwa Undang-undang Dasar Negara Republik Indonesia Tahun 1945 mengamanatkan Pemerintah mengusahakan dan menyelenggarakan satu system pendidikan nasional yang meningkatkan keimanan dan ketakwaan kepada Tuhan Yang Maha Esa serta akhlak mulia dalam rangka mencerdaskan kehidupan bangsa yang diatur dengan undang-undang. Lebih lanjut ditegaskan pada Bab I Pasal 1 ayat 1 bahwa pendidikan adalah usaha sadar dan terencana untuk mewujudkan suasana belajar dan proses pembelajaran agar peserta didik secara aktif mengembangkan potensi dirinya untuk memiliki kekuatan spiritual keagamaan, pengendalian diri, kepribadian, kecerdasan, akhlak mulia, serta keterampilan yang diperlukan dirinya, masyarakat, bangsa, dan negara. Pada Bab II Pasal 3 dijelaskan bahwa pendidikan nasional berfungsi mengembangkan kemampuan dan membentuk watak serta peradaban bangsa yang bermartabat dalam rangka mencerdaskan kehidupan bangsa, bertujuan untuk berkembangnya potensi peserta didik agar menjadi manusia yang beriman dan bertakwa kepada Tuhan Yang Maha Esa, berakhlak mulia, sehat, berilmu, cakap, kreatif, mandiri, dan menjadi warga negara yang demokratis serta bertanggung jawab.

Sementara itu pada Bab III Pasal 4 ayat 1 ditegaskan bahwa pendidikan diselenggarakan secara demokratis dan berkeadilan serta tidak diskriminatif dengan menjunjung tinggi hak asasi manusia, nilai keagamaan, nilai kultural, dan kemajemukan bangsa. Sedangkan pada ayat 2 ditegaskan bahwa pendidikan diselenggarakan dengan member keteladanan, membangun kemauan, dan mengembangkan kreativitas peserta didik dalam proses pembelajaran. Apabila 
hal-hal sebagaimana dijelaskan di atas dapat dilaksanakan dengan semestinya, maka akan menghasilkan generasi bangsa yang berkarakter kuat dan cerdas. Karakter menurut Hidayatullah (2009: 9) adalah kualitas atau kekuatan mental atau moral, akhlak atau budi pekerti individu yang merupakan kepribadian khusus yang membedakan dengan individu lain.

Masyarakat Kalimantan Barat memiliki tradisi lisan berupa cerita rakyat yang cukup beragam. Cerita-cerita rakyat tersebut diwariskan secara turuntemurun dari generasi ke generasi. Hal ini juga terimplementasikan kedalam sumber bacaan yang mudah ditemukan. Namun, sumber bacaan tersebut sering kali mendapat ketidakpedulian masyarakat dan buku tersebut menjadikan kurang diminati. Keadaan tersebut disebabkan oleh kurangnya pengetahuan mereka tentang peran dan arti penting cerita rakyat bagi masyarakat terutama bagi seluruh pelajaran maupun siswa siswi sekolah. Satu diantara cerita rakyat yang dapat menjadi sumber bacaan di sekolah dan memiliki nilai edukatif berupa Cerita Rakyat dari Kalimantan Barat 2 karya Syahzaman. Dalam buku ini mengisahkan delapan cerita rakyat Kalimantan Barat yang menjadi fokus dalam penelitian ini serta akan dibahas bagaimana relevansinya terhadap materi pembelajaran apresiasi sastra di tingkat SMA.

\section{METODOLOGI PENELITIAN}

Bentuk penelitian ini adalah deskriptif kualitatif. Penelitian kualitatif ini berdasarkan objek penelitian yang diperoleh dari data penelitian, yaitu Cerita Rakyat dari Kalimantan Barat 2 karya Syahzaman. Pendekatan penelitian yang digunakan dalam penelitian ini adalah didaktis. Pendekatan didaktis akan mendeskriptif nilai-nilai edukatif yang terdapat dalam cerita rakyat. Sumber data yang diperoleh dalam penelitian ini berupa Cerita Rakyat dari Kalimantan Barat 2 karya Syahzaman dengan genre: legenda, dan cerita rakyat. Penerbit oleh Grasindo tahun 1994, jumlah 40 halaman. Data penelitian ini berupa kutipankutipan (kata, frasa, dan kalimat) yang berkaitan dengan permasalahan dalam Cerita Rakyat dari Kalimantan Barat 2 karya Syahzaman.

Teknik pengumpulan data yang digunakan dalam penelitian ini adalah teknik analisis dokumen. Teknik analisis data yang digunakan dalam penelitian 
ini adalah teknik analisis jalinan atau mengalir yang meliputi tiga komponen, yaitu reduksi data, sajian data, dan penarikan simpulan.

\section{HASIL PENELITIAN DAN PEMBAHASAN}

Penelitian ini membahas mengenai kajian didaktis dalam Cerita Rakyat dari Kalimantan Barat 2 karya Syahzaman. Adapun yang menjadi objek penelitian yakni nilai edukatif dan relevansi Cerita Rakyat dari Kalimantan Barat 2 karya Syahzaman terhadap materi pembelajaran apresiasi sastra di tingkat SMA. Peneliti akan memaparkan "Implementasi Nilai Edukatif Cerita Rakyat Dari Kalimantan Barat 2 Karya Syahzaman dalam Relevansi Terhadap Materi Pembelajaran Apresiasi Sastra Di Tingkat Sma", untuk mengetahui nilai edukatif apa aja yang terdapat dalam Cerita Rakyat Dari Kalimantan Barat 2 Karya Syahzaman ini, peneliti menggunakan kajian didaktis. Didaktis akan memaparkan secara langsung hal-hal yang berkaitan dengan norma-norma pendidikan yang dapat memberikan prmbrlajaran terhadap pembaca untuk memiliki budi pekerti yang baik yang menggandung nilai pendidikan. Sedangkan untuk relevansi Cerita Rakyat dari Kalimantan Barat 2 karya Syahzaman terhadap materi pembelajaran apresiasi sastra di tingkat SMA penelitian ini memaparkan hasil temuan berdasarkan telaah terhadap kurikulum yang ada di sekolah.

\section{Nilai edukatif dalam Cerita Rakyat dari Kalimantan Barat 2 karya Syahzaman.}

Nilai edukatif merupakan nilai-nilai pendidikan yang di dalamnya mencakup sikap individu dalam kehidupan pribadi maupun kehidupan sosial. Nilai edukatif dalam kehidupan pribadi merupakan nilai-nilai yang digunakan untuk melangsungkan hidup pribadi, mempertahankan sesuatu yang benar, dan untuk berinteraksi. Nilai edukatif dalam Cerita Rakyat dari Kalimantan Barat 2 karya Syahzaman menggambarkan keadaan atau kebiasaan yang dilakukan oleh masyarakat Kalimantan barat dalam berkehidupan sehari-hari. Kebiasan masyarakat Kalimantan barat yang tergambar berupa hal-hal yang selalu dilakukan oleh masyarakatnya diantaranya kebiasaan bertani, percaya akan kekuatan mantra yang berhubungan dengan nilai adat, dan berhubngan dengan 
mata pencharian masyarakat maupun keadaan geografis wilayah yang berada di Kalimantan barat. Berikut ini nilai edukatif yang tergambar dalam Cerita Rakyat dari Kalimantan Barat 2 karya Syahzaman.

a. Nilai moral

"Di sebuah desa di tepi hutan, hiduplah sepasang suami istri petani. Mereka hidup sederhana. Namun mereka suka menolong orang, terutama orang yang dalam kesusahan atau yang sedang ditimpa musibah." (AMTSL, Hal.1)

Kutipan di atas memaparkan sikap tolong menolong terhapat orang lain yang mengalami kesusahan meski hidup kita sederhana. Sikap tolong menolong tersebut merupakan satu diantara nilai moral yang dapat dijadikan panutan dalam menjalani kehidupan bermasyaraakat. Sikap tersebut tentunya memberikan pembelajaran akan sikap baik seseorang yang berhubungan dengan nilai moral

"Mereka meminta emas, keluarlah emas, meminta intan berlian, keluarlah intan berlian. Tetapi sifat yang pemurah dan suka menolong orang itu tidak berubah. Banyak orang miskin dan orang yang tertimpa kesusahan mendapat pertolongan darinya." (AMSL, Hal.5)

Berdasarkan kutipan di atas petani yang berlimpahan harta lantas tidak menjadi pelit dan sombong. Justru petani tersebut semakin baik dan suka menolong. Perbuta tersebut meru[pakan gambaran nilai moral yang dapat dijadikan panutan untuk selalu membantu orang miskin maupun orang yang tertimpa kesusahan. Layaknya seorang manusia harus memiliki moral berupa sikap saling tolong menolong.

"Matahari telah tinggi, teriknya hingga menembus kulit. Sungguh panas hari itu melebihi biasanya. Sudah lama ia menunggu, tetapi tidak didapatinya satu ekor ikan pun. Namun, ia tetap bersabar menunggu. Nelayan itu tetap meneguhkan hatinya untuk menunggu dan menunggu." (AMSK, Hal.20).

Kutipan di atas menjabarkan kesabaran seorang nelayan menunggu untuk mendapatkan ikan meski panas matahari membakar kulitnya. Kesabaran tersebut merupakan bagian dari nilai moral yang dapat dijadikan panutan bagi manusia. Sabar merupakan perbutan yang tulus dan tidak ada batasannya. Sabar merupakan kelapangan hati yang harus dimiliki seseorang. 


\section{b. Budi pekerti}

"Di sebuah desa di tepi hutan, hiduplah sepasang suami istri petani. Mereka hidup sederhana." (AMTSL, Hal.1)

Kutipan di atas menunjukan watak atau karakter seorang petani pada umumnya. Seorang petani yang bermukim bersama keluarganya di tepi hutan hidup dengan sederhana. Kesederhanan termasuk dalam budi pekerti yang menggambarkan watak sederhana yang dapat di contoh.

"inilah kesempatan bagik untuk menarik simpati penduduk," piker perampok itu. "mereka akan hormat kepada ku. Mungkin juga mereka akan mengangkatku menjadi pemimpin." Perampok itu menghayal kehebatannya menjadi pemimpin." (AMSL, Hal.5)

Paragraf di atas menjelaskan bahwa perampuk tersebut ingin dihormati dan diangkat menjadi pemimpin berkat barang hasil curiannya yang dapat memgabulkan semua keinginan. Sifat tersebut merupaka gambaran nilai budi pekerti yang tidak baik dan tidak pantas untuk dicontoh. Watak atau karakter yang mucul dalam budi pelerti perampok tersebut merupakan perbuatan tercela.

"Potong saja kawatnya, jangan diteruskan!"

Namun, nelayan itu sudah keras hatinya. Air pelan-pelan memenuhi perahu, karena tidak kuat menanggung beban gulungan kawat yang demikian banyak. Ia terus saja menarik kawat dari dalam sungai. Ia baru tersadar, ketika perahu hampir karam. Akan tetapi, kesadaran itu terlambat. Nasi sudah menjadi bubur. Nelayan tak sempat lagi menyelamatkan diri. (AMSK, Hal.20)

Kutipan di atas merupakan bentuk budi pekerti yang tidak baik dan tidak dapat di contoh. Budi pekerti dalam deskripsi di atas berupa watak serahkah manusia yang tidak pernah puas akan segala hal. Termasuk nelayan tersebut yang tidak sadar perahunya sampai karam kerna mengangkat emas yang berlebihan dari sungai.

c. Nilai Adat (Tradisional)

"Pada waktu itu petani tersebut sedang duduk-duduk melepaskan lelah di tengah ruangan pondok mereka yang kecil. Istri petani itu sedang tidur di sampingnya. Mungkin karena lelah seharian bekerja di ladang." (AMTSL, Hal.1) 
Kutipan tersebut menggambarkan kebiasan yang dilakukan petani stelah lelah bekerja di ladang mereka akan kembali ke pondoknya yang beritirahat. Tidur di pondok setelah bertani merupak suatu kebiasan yang dilakukan petani. Kebiasan tersebut masuk dalam gambaran nilai adat atau tradisonal.

"Setelah dirasa cukup, petani itu lalu membaca mantra untuk menghentikan beras yang keluar. Jadi mantra untuk mengeluarkan dan matra untuk menghentikan tidak sama." (AMSL, Hal.4)

Kutipan diatas menggambarkan tradisi atau kebiasan yang termasuk dalam nilai adat masyarakat zaman dahulu yang percaya akan kekuatan-kekuatan gaib. Setelah mendapatkan patung landing emas petani membaca mantra dan meminta beras, sehingga keluarlah beras tersebut dari mlut landak emas.

"Perampok itu membawa bungkusan kain kuning. Tak seorangpun tahu aoa yang ada di dalam bungkusan itu. Ia duduk dan mulai mengusap bungkusan, mulutnya komat-kamit membaca mantra." (AMSL, Hal.5)

Paragraph di atas menjabarkan suatu kebiasan yang dilakukan pada masyarakat daerah Kalimantan barat yakni benda yang dianggap pusaka akan selalu dibungkus oleh kain berwarna kuning. Warna kuning dilampangkan sebagai warna kemakmuran, warna kerajaan, dan warna kesakralan. Sehingga kutipan tersebut memberikan gambaran tentang kebiasan yang dilakukan sesorang terhadap nbenda psakanya yang dianggap memiliki kekuatan gaib.

"Suku Dayak ini mempunyai keahlian dalam memahat dan mengukir kayu. Ada beberapa jenis ukiran yang mereka buat, ada ukiran biasa, ukiran kerrawang atau ukiran tembus. Mereka mengukir rumah, mengukir peti, lesung padi, alu penumbuk padi, dampai perahu." (AUSDLN, Hal.7)

Kutipan di atas memaparkan kebiasan masyarakat suku Dayak yang gemar memahat dan mengukir kayu. Hal tersebut terlihat dari berbagai alat yang digunakan masyarakat suku dayat semuanya memiliki ukiran atau pahatan. Kebiasaan mengukir atau memahat merupana suatu teradisi yang diwarisi terun temurun olah suku Dayak. Kebiasan tersebut erupaka satu diantara gambaran nilai adat yang terdapat pada masyrakat suku Dayak.

"Mereka berbicara dalam bahasa Dayak, tetapi aksennya adalah aksen jawa." (AUSDLN, Hal.7) 
Kutipan tersebut merupakan tradisi suku Dayak Lenbang Nando yang menggunakan bahasa dayak dengan aksen jawa. Bahasa merupakan gambaran nyata akan nilai adat. Nilai adat yang berhubungan dengan bahasa bukan hanya menjadi kebiasaan tapi juga menadi ciri khas dari setiap masyarakat

\section{d. Nilai sejarah}

"Setelah menndapatkan landak emas asli, perampok tersebut melarikan diri ke daerah Ngabang. Di sana waktu itu musim kemarau panjang. Pendudk menderita kekuragan air, sungai-sungai kecil semuanya kering. Dimana-mana penduduk mengeluh: air ... air. Tidak lain hanya air yang mereka butuhkan." (AMSL, Hal.5)

Paragraph di atas menggambarkan keadaan yang berhubungan dengan sejarah atau keadaan masa lampau. Dimana pernah terjadi musim kemarau panjang dan deerah Ngabang dilanda kekeringan. Masyarakat hanya dapat mengeluh dan memncoba bertahan dari kebutuhannya akan air bersih karena semua sungai mengering dan hujan tidak kunjung turun.

"Air bertambah dan mengalir terus membentuk sungai. Kemudian penduduk menyebutnya debgan sungai landak, karena iarnya keluar dari tubunh seekor landak emas. Akhirnya perampok tenggelam bersama landal emas." (AMSL, Hal.6)

Kutipan di atas merupan sejarah asal mulai terjadinya sunga landak. Hal ini dipercaya oleh masyarakat Kalimantan Barat khususnya daerah Ngabang. Sungai landak berasal dari sifat angkuh perampok yang meminta air dari patung landak emas namun tak bias menghentikan air tersebut agar berhenti mengalir. Deskripsi di atas merupakan gambaran masa lalu sungai landk yang termasuk dalam sejarah Kalimantan barat.

"Suku Dayak Lebang Nando ini tinggal di kawasan Kabupaten Sintang yang sekarang, yaitu di bagaian pedalaman provinsi Kalimantan Barat." (AUSKLN, Hal. 7)

Kutipan tersebut mengambarkan daerah yang didiami oleh suku Dayak Lebang Nando yang berdiam di kawasan kabupaten Sintang. Kutipan tersebut memberikan nilai sejarah pada wilayah tempat tinggal awal suku Dayak Lebang Nando.

"Dikisahkan, ada seorang nelayan dan keluarganya tinggal dekat sungai di kota Sintang, Kalimantan Barat. Kehidupan mereka sungguh sangat 
sederhana. Bahkan, dapat dikatakan serba kekurangan. Sehari-hari nelayan itu menangkap ikan di sungai untuk memenuhi kebutuhan hidup keluarga.” (AMSK, Hal.19)

Deskripsi di atas menjabarkan keadaan masyarakat di dekat sungai di kota Sintang Kalimantan Barat yang bekerja sebagai nelayan. Peryataan tersebut memberikan gambaran nilai sejarah berupa wilayah tempat tinggal nelayan yang berada dekat sungai di kota Sintang.

Hal yang sama di kota Sintang yang menggambarkan nilai sejarah juga tergambar dalam kutipan di bawah ini:

"Ia mati sia-sia, karena menuruti nafsu serakahnya. Di kemudian hari, peristiwa tersebut menjadi pertanda bagi semua orang untuk menahan diri dari nafsu yang tidak bertepi. Sungai tempat tenggelamnya si nelayan diberi nama sungai Kawat. Itulah asal-usul nama Sungai Kawat." (AMSK, Hal.21)

Kutiapan di atas menggambarkan peristiwa yang dialami oleh sorang nelayang yang mati tenggelam karena keserahkahannya mengambil kawan emas yang mengait pada pancingannya sampai terlupa bahwa perahunya akhirnya karam tenggelam kedasar sungai. Sungai Kawat menjadi unsur nilai sejarah. Nilai sejarah tersebut berupa lokasi sungai yang berasa di kota sintang yang diberi nama sungai Kawat.

"Liang Mengurang terletak di Kabupaten Kapuas Hulu, Propinsi

Kalimantan Barat. Kabupaten Kapuas Hulu terletak di tengah Pulau Kalimantan. Liang Mengurang berbentuk datar.” (LM, Hal.22)

Kutipan di atas menggambarkan sebuah liang yang berbentuk datar yang berada di kabupaten Kapuas Hulu Kalimantan Barat. Nilai sejarah yang terdapat dalam kutipan tersebut berupa wilayah liang yang berbentuk datar yang disebut dengan Liang Megurang.

Kutipan lainnnya yang berhubungan dengan Liang Megurang juga mengandung nilai sejarah terdapat pada kutipan di bawah ini:

"Legenda Liang Mengurang bermula dari sebuah peristiwa yang terjadi pada zaman permulaan penjajahan Belanda di daerah Kalimantan Barat.”(LM, Hal.21) 
Paragraf di atas menjabarkan awal kisah legenda tentang Liang Mengurang yang dimulai saat zaman penjajahan Belanda di Kalimantan Barat. Nilai sejarah dalam paragraph tersebut merupakan gambaran peristiwa yang terjadi pada masa penjajahan belanda di sebuah Liang di kawasan kabupaten Kapuas Hulu Kalimantan Barat.

\section{Relevansinya Cerita Rakyat dari Kalimantan Barat 2 karya Syahzaman terhadap materi pembelajaran apresiasi sastra di tingkat SMA.}

Selain niali edukatif ditemukan juga relevansi antara Cerita Rakyat dari Kalimantan Barat 2 karya Syahzaman dengan pembelajaran apresiasi sastra di SMA dimana pembelajaran tersebut seiring dengan kurikulum yang berlaku saat ini yakni kurikukulum K13. Hal ini juga disetuji oleh informan yang berkeja sebagai pengajar di SMA. Proses pembelajaran sastra khususnya cerita rakyat merupakan bagian dari pendidikan karakter, untuk itu secara aktif peserta didik dapat mengembangkan potensi diri supaya memiliki kekuatan spiritual keagamaan, pengendalian diri, kepribadian, kecerdasan, akhlak mulia merupakan bagian dari pendidikan berbasis karakter. Pada setiap Institusi-Institusi memiliki beban tugas sekolah masing-masing, guru berperan tidak hanya membangun, meningkatkan, informasi yang diperoleh peserta didik, melainkan harus bertanggung jawab terhadap peserta didik dalam kapasitas pengambilan keputusan yang bijak dalam kehidupan.

UU Nomor 20 Tahun 2003 tentang Sistem Pendidikan Nasional Bab I Pasal I Ayat I dikatakan, "pendidikan adalah usaha sadar dan terencana untuk mewujudkan suasana belajar dan proses pembelajaran peserta didik secara aktif mengembangkan potensi dirinya untuk memiliki kekuatan spiritual keagamaan, pengendalian diri, kepribadian, kecerdasan, akhlak mulia, serta keterampilan yang diperlukan dirinya, masyarakat, bangsa, dan Negara". Dari pemaparan basis pendidikan sebagaimana diamanatkan oleh UNESCO, secara ekmplisit sangat relevan dengan cita-cita yang diamanatkan dalam UU Nomor 20, tahun 2003.

Proses pembelajaran sastra khususnya cerita rakyat merupakan bagian dari pendidikan karakter, untuk itu secara aktif peserta didik dapat mengembangkan potensi diri supaya memiliki kekuatan spiritual keagamaan, pengendalian diri, 
kepribadian, kecerdasan, akhlak mulia merupakan bagian dari pendidikan berbasis karakter. Pada setiap Institusi-Institusi memiliki beban tugas sekolah masingmasing, guru berperan tidak hanya membangun, meningkatkan, informasi yang diperoleh peserta didik, melainkan harus bertanggung jawab terhadap peserta didik dalam kapasitas pengambilan keputusan yang bijak dalam kehidupan. Dengan demikian, Mann sejalan dengan Dewey, mengemukakan bahwa seorang filsuf pendidikan, tujuan utama pendidikan adalah sebagai penggerak efesiensi pendidikan, pembentuk kebijakan berkewarganegaraan, dan penciptaan manusia berkarakter, jadi bukan untuk kepentingan salah satu pihak tertentu (Jihad et al 2010: 61).

Barnawi (2012:67) menjelaskan bahwa terdapat empat model yang dapat dilakukan sebagai alternatif dalam mengimplementasikan pendidikan karakter di sekolah, yaitu model otonomi dimana pendidikan karakter dilakukan sebagai mata pelajaran sendiri. Selain model otonomi juga terdapat model integrasi, yaitu nilainilai dan karakter- karakter disatukan dan dibentuk pada setiap mata pelajaran. Model ekstrakurikuler juga digunakan sebagai kegiatan tambahan yang dapat berorientasi pembinaan karakter pada peserta didik. Model kolaborasi yaitu model yang dilakukan dengan cara menggabungkan model otonomi, model integrasi, dan model ekstrakurikuler dalam seluruh rangkaian kegiatan di sekolah.

Salah satu bentuk upaya yang dapat dilakukan untuk mengembangkan dan menanamkan nilai-nilai pendidikan karakter pada peserta didik adalah dengan mengoptimalkan pembelajaran apresiasi dongeng di sekolah hal ini terpapar dalam wawancara yang di lakukan bersama ibu Lora Tri Yulianti, M.Pd sebagai guru pengajar Bahasa Indonesia di Sekolah Menengah Atas (SMA) Santun Untan). Dari hasil wawancara tersebut juga di temukan bahwa menurut informan nilai-nilai pendidikan karakter yang diintegrasikan dalam pembelajaran apresiasi dongeng tertuang dalam isi materi dan kegiatan pembelajaran di kelas. Isi materi apresiasi dongeng dapat dikemas dan disusun sedemikian rupa sesuai dengan kebutuhan peserta didik dan guru yang berdasarkan nilai-nilai pendidikan karakter. Pembelajaran tentang dongeng atau cerita rakyat ini juga terdasap dalam pemetaan KD dan IPK di bawah ini: 
Kompetensi Dasar ( KD) dan Indikator Pencapaian Kompetensi (IPK)

\begin{tabular}{|c|c|}
\hline Kompetensi Dasar & Indikator \\
\hline \multirow{3}{*}{$\begin{array}{l}\text { 3.7 Mengidentifikasi nilai- nilai dan isi yang } \\
\text { terkandung dalam cerita rakyat (hikayat) baik } \\
\text { lisan maupun tulis. }\end{array}$} & $\begin{array}{l}\text { 3.7.1 Menentukan ciri- } \\
\text { ciri/karakteristik hikayat }\end{array}$ \\
\hline & $\begin{array}{l}\text { 3.7.2 Menentukan unsur } \\
\text { intrinsik dan ekstrinsik } \\
\text { hikayat }\end{array}$ \\
\hline & $\begin{array}{l}\text { 3.7.3 Menentukan nilai- } \\
\text { nilai hikayat }\end{array}$ \\
\hline \multirow[t]{2}{*}{$\begin{array}{l}4.7 \text { Menceritakan kembali isi cerita rakyat } \\
\text { (hikayat) yang didengar dan dibaca. }\end{array}$} & $\begin{array}{l}\text { 4.7.1 Menceritakan kembali } \\
\text { isi hikayat }\end{array}$ \\
\hline & $\begin{array}{l}\text { 4.7.2 Menanggapi } \\
\text { hikayat }\end{array}$ \\
\hline
\end{tabular}

Nilai-nilai tersebut tertuang dalam ilustrasi, tema, contoh-contoh, gambargambar, latihan, dan dalam kegiatan belajar peserta didik. Nilai-nilai pendidikan karakter tersebut disampikan secara tersirat, relevan dengan peserta didik, dan mudah diaplikasikan dalam kehidupan sehari-hari peserta didik. Hal tersebut dilakukan dengan tujuan agar peserta didik benar-benar dapat mengaplikasikan nilai-nilai pendidikan karakter dalam kehidupan nyata. Dengan demikian, peserta didik diharapkan dapat menanamkan nilai-nilai pendidikan karakter dalam jiwa mereka dan bukan hanya ketika di sekolah atau selama proses pembelajaran saja. Antara guru, peserta didik, sekolah, keluarga, dan lingkungan harus terdapat kolaborasi dalam proses pembeltukan karakter peserta didik agar hasil yang diharapkan dapat maksimal.

Sastra mengandung nilai adiluhung, Wibowo (2013: 104) memberi batasan, bahwa sastra adiluhung adalah kehidupan dunia yang bersifat dinamis, bersifat relatif, dan bukan ekslusif. Penilaian sastranya pasti berkaitan dengan karakter kepribadian setiap manusia. Karena tingkat apresiasinya terlalu tinggi terhadap, sastra adiluhung sangat bermutu sebagai lantaran yang mampu menghaluskan rohaniah; mempertajam visi, mempertajam misi dan mempertajam ruang imajinasi, dengan hal ini tetntunya akan membuat manusia menjadi santun 
jiwanya, bertambah wawasan ilmu pengetahuannya, memiliki kepribadian yang mulia, dan luas jiwanya. Informan juga mengungkapkan bahwa pembelajaran apresiasi dongeng memiliki peran penting terhadap perkembangan karakter seseorang. Dalam cerita dongeng mengandung nilai-nilai kehidupan sebagai salah satu bagian dalam pendidikan karakter pada generasi muda untuk mengantisipasi generasi digital dan usaha sadar merespon kehidupan global. Penanaman pendidikan karakter di Indonesi diwujudkan melalui Kurikulum 2013 seperti pendapat infoman mengatakan, perubahan KTSP ke Kurikulum 2013 sesungguhnya guna merespons dan mengantisipasi perkembangan, tuntutan kebutuhan manusia dalam menghadapi Masyarakat Ekonomi Asean.

\section{SIMPULAN}

Nilai edukatif terkandung dalam Cerita Rakyat dari Kalimantan Barat 2 karya Syahzaman. Nilai-nilai edukatif berupa niali moral, nilai adat (tradisional), nilai budi pekerti, dan nilai sejarah yang memberikan gambaran kebiasaan baik prilaku masyarakat Kalimantan barat. Relevansi Cerita Rakyat dari Kalimantan Barat 2 karya Syahzaman terhadap pembelajaran di SMA relevan dengan kurikulum dan kebutuhan siswa pada saat ini. Relevansi tersebut juga tergambar dalam kurikukum K13 yang diterapkan di sekolah-sekolah menengah atas dan sejalan dengan hasil wawancara bersama infoman.

\section{DAFTAR PUSTAKA}

Ahmadi \& Uhbiyati. (1991). Ilmu Pendidikan. Jakarta: Rineka Cipta.

Bascom, W, R. (1965). The Form of Folklore: Prose Narrative. The Hague: Mouton.

Burhan, N. (2002). Teori Pengkajian Fiksi. Yogyakarta: Gadjah Mada University Press.

Franz, M, S. (2000). 12 Tokoh Etika Abad ke-20. Yogyakarta: Kanisius.

Frondizi, R. (2001). Pengantar Filsafat Nilai (Edisi terjemahan oleh Cuk Ananta Wijaya). Yogyakarta: Pustaka Pelajar.

Haviland, W, A. (1993). Antropologi (Edisi Terjemahan oleh R. G. Soekadijo). Jakarta: Erlangga. 
Herman J, W. (1990). Apresiasi Prosa dan Drama. Surakarta: UNS Press. . (2002). Apresiasi dan Pengkajian Fiksi. Salatiga: Widya Sari Press.

James, D. (1977). Folklor Indonesia: Ilmu Gosip, Dongeng, dan lain-lain. Jakarta: Grafiti.

Koentjaraningrat. (1984). Kebudayaan, Mentalitas, dan Pembangunan. Jakarta: Gramedia.

Liaw, Y, F. (1982). Sejarah Kesusasteraan Melayu Klasik. Singapura: Pustaka Nasional Pte. Ltd.

Melani, B., \& Ida, S, H., \& Manneke, B., \& Ibnu, W. (2002). Membaca Sastra: Pengantar Mahasiswa Memahami Sastra untuk Perguruan Tinggi. Magelang: Indonesiatera.

Mudji, S. (1997). Sari-sari Pencerahan. Yogyakarta: Kanisius.

Panuti, S. (1988). Memahami Cerita Rekaan. Jakarta: Pustaka Jaya.

Rahmanto, B. (1988). Metode Pengajaran Sastra. Yogyakarta: Kanisius.

Suwardi, E. (2003). Budi Pekerti dalam Budaya Jawa. Yogyakarta: Anindita.

Teeuw, A. (2003). Membaca dan Menilai Sastra. Jakarta: Gramedia.

Zainuddin, F. (2001). Telaah Sastra. Surakarta: Muhammadiyah University Press. 